\title{
Amaranthus
}

Volume 1990 | Issue 2

Article 30

1990

\section{Some Thoughts Concerning Education}

Carmen Lowe

Grand Valley State University

Follow this and additional works at: https://scholarworks.gvsu.edu/amaranthus

\section{Recommended Citation}

Lowe, Carmen (1990) "Some Thoughts Concerning Education," Amaranthus: Vol. 1990: Iss. 2, Article 30. Available at: https://scholarworks.gvsu.edu/amaranthus/vol1990/iss2/30

This Article is brought to you for free and open access by ScholarWorks@GVSU. It has been accepted for inclusion in Amaranthus by an authorized editor of ScholarWorks@GVSU. For more information, please contact scholarworks@gvsu.edu. 
Some Thoughts Concerning Education

Carmen Lowe

I can't come to class

on days like these

when the earth promises

dandelions and hints at trilliums.

Sand Creek is still too cold

for wading, but just right for cooling

silver-scaled six packs of beer.

We'll be there on days like these,

skipping class to skip stones

and totter across the springling rapids

on winter-felled pine-bark bridges .

We've moved the classroom

to the sand-bottomed creek,

so you might as well come with us,

when winter clouds

fall through the thin-iced sky

and drown in the blue. 